\title{
ANALISIS PERBEDAAN KOMITMEN PROFESIONAL DAN SOSIALISASI ANTISIPATIF MAHASISWA BIDIKMISI DAN NON-BIDIKMISI PADA HUBUNGANNYA DENGAN WHISTLEBLOWING (Studi Kasus Pada Mahasiswa Akuntansi Universitas Malikussaleh)
}

\author{
Muhammad Yusra ${ }^{1}$ Nur Afni Yunita ${ }^{2}$ Nurhasanah $^{3}$ \\ 1,2 Prodi Akuntansi Fakultas Ekonomi dan Bisnis Universitas Malikussaleh Lhokseumawe \\ myusra@unimal.ac.id, nurafni.yunita@unimal.ac.id, nurhasanah@unimal.ac.id
}

\begin{abstract}
This study aims to look at the effect of professional commitment and anticipatory socialization of bidikmisi and non-bidikmisi accounting students at Malikussaleh University on its relationship with whistleblowing. In addition, this study also aims to see differences in the level of professional commitment and anticipatory socialization between students of Bidikmisi and non-Bidikmisi Accounting at Malikussaleh University. Sampling in this study using the Slovin formula is a sampling technique that uses a critical value or accuracy limit of 0.1 , so that the sample obtained in this study amounted to 90 respondents from a total population of 286 students. This study uses multiple regression analysis techniques with hypothesis testing using the SPSS 22 program. The results show that professional commitment and anticipatory socialization affect whistleblowing, as well as differences in the level of professional commitment and anticipatory socialization between bidikmisi and non-bidikmisi students at Malikussaleh University.
\end{abstract}

Keywords: Whistleblowing, Professional Commitment, and Anticipatory Socialization.

\section{PENDAHULUAN}

Etika profesi akuntan pada saat ini merupakan hal yang sangat marak diperbincangkan oleh masyarakat karena berkurangnya kepercayaan masyarakat terhadap profesi akuntan itu sendiri. Alasan yang menyebabkan berkurangnya kepercayaan masyarakat terhadap profesi akuntan adalah banyaknya tindakan kecurangan yang dilakukan oleh akuntan. Association of Certified Fraud Examiners (ACFE) mengatakan bahwa setiap tahun rata-rata 5\% pendapatan organisasi menjadi korban kecurangan.

Kasus-kasus skandal besar masalah kecurangan keuangan yang dilakukan oleh akuntan terjadi di perusahaan-perusahaan besar baik di luar negeri maupun didalam negeri. Selain itu juga, (Aridyanti, 2019) mengatakan di lingkungan perguruan tinggi kasus kecurangan yang dilakukan oleh mahasiswa disebut kecurangan akademik. Seperti pada saat mendapatkan tugas dari dosen, mahasiswa biasanya menduplikat hasil tugas temannya, juga disaat ujian berlangsung mahasiswa mencontek hasil ujian teman. Tidak jarang pula masih ditemukannya mahasiswa yang melakukan titip absen.

Banyaknya kasus-kasus kecurangan akuntansi menyebabkan hilangnya kepercayaan publik dan meningkatnya campur tangan pemerintah Pada gilirannya menimbulkan dan membawa kepadaruntuhnya profesi akuntan. Dimana, komitmen akan profesionalisme seorang akuntan dan calon akuntan diragukan. Salah satu cara mengungkapkan pelanggaran akuntansi sehingga dapat mengembalikan kepercayaan masyarakat adalah dengan melakukan whistleblowing.

Menurut (Efendi, 2009: 224) whistleblowing adalah pengungkapan tindakan pelanggaran atau perbuatan yang melawan hukum yang dapat merugikan perusahaan atau organisasi maupun pemangku kepentingan, yang disampaikan oleh pihak internal atau eksternal kepada pemimpin perusahaan yang selanjutnya dapat dilakukan tindakan atas pelanggaran tersebut.

Banyak faktor yang dapat mempengaruhi niat seseorang sehingga seseorang tersebut akan mengambil keputusan untuk melakukan atau tidak melakukan whistleblowing. Seperti menurut teori tindakan beralasan, niat merupakan suatu fungsi yang dipengaruhi dua faktor yang saling berhubungan. Faktor pertama dipengaruhi oleh pribadi diri sendiri (komitmen profesional) dan yang kedua faktor social (sosialisasi antisipatif).

Universitas Malikussaleh merupakan salah satu dari 10 Universtitas penerima bidikmisi terbanyak di Indonesia pada tahun 2016, 2017 dan 2018. Tentunya semakin banyak penerima beasiswa bidikmisi di dalam suatu Universitas makan semakin tinggi pula tingkat kecurangan yang terjadi pada Universitas tersebut. Sebuah berita yang diterbitkan oleh unimal news membuktikan pernyataan tersebut. Pada akhir tahun 2019 lalu, banyak penerima bidikmisi Universitas Malikussaleh yang melakukan kecurangan berupa, tidak memenuhi target prestasi, apakah dari segi tidak melanjutkan pendidikanya di 
program beasiswa yang dipilih ataupun IPK yang menurun, atau tidak memenuhi persyaratan minimal IPK 2,75 dan lebih dari 1000 mahasiswa yang tidak memenuhi persyaratan IPK tersebut (Riyandhi, 2019). Hal tersebut menunjukan tidak komitmennya mahasiswa terhadap persyaratan beasiswa bidikmisi yang sedang dijalani.

Selain itu saya juga melakukan survey berupa memberikan kuesioner on-line terhadap 50 mahasiswa akuntansi bidikmisi Universitas Malikussaleh. Untuk melihat kecurangan yang terjadi secara khusus di ruang lingkup mahasiswa akuntasi Universitas Malikussaleh. Dengan beberapa item pertanyaan yang peneliti kembangkan dari syarat-syarat penerima besiswa bidikmisi seperti:

1. Usia paling tinggi pada saat mendaftar $21 \mathrm{thn}$.

2. Tidak mampu secara ekonomi dengan kriteria memiliki pendapatan gabungan orangtua Rp.750.000. perbulan.

3. Pendidikan orang tua/wali setinggi-tingginya S1 atau D4.

4. Realisasi pribadi mahasiswa saat pencairan beasiswa bidikmisi.

Dari beberapa pertanyaan diatas yang di berikan kepada 50 mahasiswa akuntansi bidikmisi Universitas Malikussaleh menunjukan hasil sebagai berikut:

\section{Realisasi Pribadi Mahasiswa Saat pencairan Beasiswa Bidikmisi}

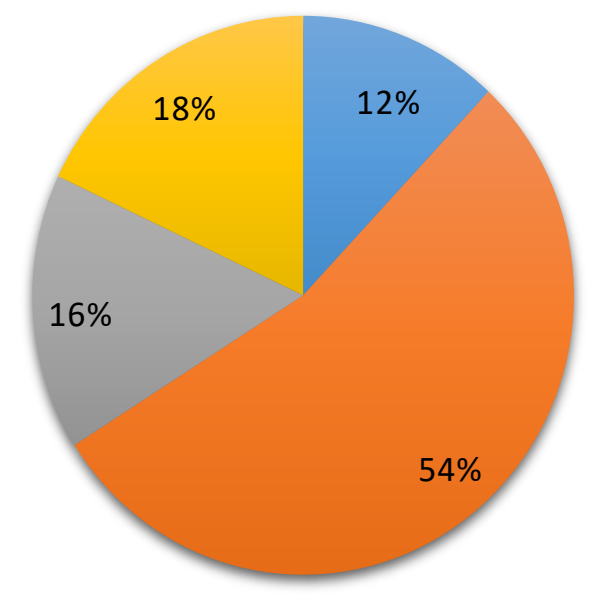

Berdasarkan survai yang peneliti lakukan pada mahasiswa akuntansi yang bidikmisi Universitas Malikussaleh, realisasi pribadi mahasiswa yang paling banyak dibelanjakan untuk membeli Smartphone dan paling rendah dibelanjakan untuk membeli buku (keperluan akademik lainnya). Hal tersebut dapat dilihat dari diagram lingkaran 1.1 yang menyatakan bahwa, sebanyak 27 responden atau 54\% memilih membeli smartphone, $18 \%$ menyimpan sebagai tabungan, $15 \%$ dibelanjakan untuk membeli barang konsumtif (pakaian, make up, dan lainya), dan 12\% memilih untuk membeli buku (keperluan akademik lainnya). Hal tersebut mengindikasikan bahwasanya telah terjadi kecurangan pada mahasiswa akuntansi bidikmisi tersebut.

Karena smartphone disini dianggap tidak sepenuhnya kebutuhan dari mahasiswa bidikmisi. Walaupun, smartphone pada saat ini merupakan bagian dari pendukung akademik. Namun, kebanyakan mahasiswa justru menyalahgunakan smartphone ini hanya sebagai sarana sosial media saja dan bahkan bannyak mahasiswa yang menurun prestasinya akibat sering menggunakan smartphone untuk bermain game online. Selain hal tersebut, kecurangan lainya terindikasi dari rendahnya mahasiswa bidikmisi yang membeli buku saat pencairan bidikmisi. Karena, sebagaimana diketahui bahwasanya, buku merupakan kebutuhan pokok mahasiswa. Karena kecurangan yang dilakukan oleh mahasiswa akuntansi bidikmisi Universitas Malikussaleh tersebut menunjukkan bahwa tidak komitmennya mahasiswa tersebut terhadap persyaratan awal saat mahasiswa mengaku berhak mendapatkan beasiswa bidikmisi.

Fenomena ini diperkuat dengan beberapa penelitian yang telah dilakukan salah satunya penelitian yang dilakukan oleh (Setiyawan, 2016) dengan judul Analisis Perbedaan Komitmen Profesional dan Sosialisasi Antisipatif Mahasiswa Udinus dan Unika Soegijapranata pada Hubungannya Dengan whistleblowing yang menunjukan hasil bahwa komitmen profesional berpengaruh terhadap whistleblowing. Tetapi pada variabel sosialisasi antisipatif tidak berpengaruh terhadap whistleblowing. Pada pengujian uji beda, didapatkan hasil bahwa terdapat perbedaan komitmen profesional antara UDINUS dan UNIKA Soegijapranata. Pada variabel sosialisasi antisipatif, persepsi whistleblowing dan whistleblowing intention tidak terdapat perbedaan pada kedua universitas.

Dari penelitian-penelitian diatas peneliti juga tertarik untuk meneliti tentang perbedaan persepsi mengenai komitmen profesional dan sosialisasi antisifatif dan hubungan-nya dengan whistleblowing pada mahasiswa bidikmisi dan nonbidikmisi, karena sebagaimana diketahui bahwa pada Universitas Malikussaleh mahasiswa bidikmisi rutin mendapatkan pelatihan khusus softskill setiap 
tahunnya dibandikan mahasiswa non-bidikmisi Diharapkan mahasiswa bidikmisi lebih memiliki komitmen profesional dan sosialisasi antisipatif lebih tinggi dibandingkan mahasiswa non-bidikmisi dan peneliti juga mengharapkan adanya perbedaan persepsi antara mahasiswa bidikmisi dan nonbidikmisi mengenai whistleblowing dan whistleblowing Itention.

Kerena didalam pelatihan softkill tersebut mahasiswa bidikmisi diajarkan beberapa hal seperti, berpikir kritis, komunikasi yang baik, mengakses dan manganilis mensintesis informasi, rasa ingin tahi dan inovativ yang tinggi, kepemimpinan, kemapuan beradaptasi, kerjasama seta kolaborasi, public speaking, manajemen waktu, dan networking. Dengan hal-hal yang diberikan tersebut kepada mahasiswa bidikmisi, mengindikasikan bahwa mahasiswa bidikmi ini lebih siap dibandingkan mahasiswa non-bidikmisi saat nanti akan memasuki dunia kerja, dan diharapkan mahasiswa bidikmisi tersebut lebih memiliki komitmen profesional dan sosialisasi antisipatif lebih tinggi dibandingkan mahasiswa non-bidikmisi. Dengan tingginnya tingkat komitmen profesional dan sosialisasi antisipatif tersebut tentunya juga akan mempengaruhi persepsi mereka akan pentingnya whistleblowing.

\section{TINJAUAN PUSTAKA}

\section{Landasan Teoritis}

Teori tindakan beralasan atau yang disingkat dengan TRA (Theory of Reasoned Action) muncul dari penelitian sebelumnya yang kurang berhasil, atas pengujian teori sikap yang berhubungan antara sikap dan perilaku. Menurut teori tindakan beralasan, niat merupakan suatu fungsi yang dipengaruhi dua faktor yang saling berhubungan. Faktor pertama dipengaruhi oleh pribadi diri sendiri dan yang kedua faktor sosial (Malik, 2010)

Dalam penelitian ini faktor pribadi dalam diri seorang mahasiswa digambarkan sebagai komitmen mereka terhadap etika profesi akuntan yang akan dijalani setelah memasuki dunia kerja (komitmen profesional). Sedangkan pengaruh sosial yang ada dijelaskan dengan sosialisasi antisipatif kepada mahasiswa akuntansi mengenai pentingnya berpegang pada etika profesi saat mereka memasuki dunia kerja oleh institusi pendidikan yang ada. Komitmen profesional dan sosialisasi antisipatif sebagai norma subyektif akan membentuk minat mahasiswa untuk melakukan whistleblowing atau pengungkapan kecurangan pada instansi di mana dia bekerja nantinya.

Ditambah lagi oleh pendapat menurut Fishbein dan Ajzen dalam (Pangesti \& Rahayu, 2017) mengatakan bahwa tujuan utama dari teori tindakan beralasan ialah untuk memprediksi dan memahami perilaku individu manusia. Seperti yang telah dijelaskan, intensi seseorang merupakan fungsi dari dua fakor penentu yang terdapat dalam teori tindakan beralasan yaitu sifat kepribadian seseorang yang disebut sikap dimana, komponen ini memerankan variabel komitmen profesional dan pengaruh sosial yang disebut norma subjektif yang memerankan variabel sosialisasi antisipatif.

\section{Perbedaan Mahasiswa Bidikmisi dan Non- Bidikmisi}

Mahasiswa adalah sebutan bagi orang yang sedang menempuh pendidikan tertinggi disebuah perguruan tinggi yang terdiri atas sekolah tinggi, akademik, dan paling umum adalah Universitas. Sepanjang sejarah, mahasiswa diberbagai Negara mengambil peran penting dalam sejarah suatu Negara. Bidikmisi adalah program bantuan biaya pendidikan yang diberikan pemerintah melalui direktoran jendral pendidikan tinggi kementrian pendidikan dan kebudayaan mulai tahun 2010 kepada mahasiswa yang memiliki potensi akademik memadai dan kurang mampu secara ekonomi. Jadi, dapat disimpulkan bahwa mahasiswa bidikmisi adalah seseorang yang sedang menempuh pendidikan tinggi disebuah peguruan tinggi yang dengan bantuan biaya pendidikan pemerintah kepada mahasiswa tersebut (Belmawabidikmisi, 2019).

Jika dilihat dari segi pemberian fasilitas pelatihan softskill antara mahasiswa bidikmisi dan non-bidikmisi pada Universitas Malikusaleh tentunya diharapkan mahasiswa bidikmisi memiliki pengetahuan softskill lebih tinggi dibandingkan mahasiswa non-bidikmisi karena telah mendapatkan pelatihan rutin setiap tahunya. Selain itu juga (Utami, 2016) mengatakan bahwa mahasiswa bidikmisi dengan segala keterbatasannya memiliki tanggung jawab lebih besar dari pada mahasiswa non-bidikmisi karena dituntut untuk dapat lulus kurang dari empat tahun agar beasiswa tidak dicabut, serta dituntut agar lebih berprestasi pada bidang akademik maupun non-akademik, selain itu diharapkan juga dapat aktif dalam kegiatan organisasi.

Penelitian (Utami, 2016) menunjukan hasil bahwa mahasiwa bidikmisi memiliki rata-rata skor tingkat kecerdasan advertsity lebih tinggi dari pada mahasiswa Non-Bidikmisi. Selanjutnya penelitian yang (Chomsyatun, 2018) menunjukan bahwa beasiswa bidikmisi berpengaruh terhadap motivasi berprestasi Universitas Negri Islam Radien Intan Lampung sebesar $27,7 \%$ dibandingkan mahasiwa non-bidikmisi. Jadi, dari penjelasan-penjelasan tersebut memungkinkan adanya perbedaan komitmen profesional dan sosialisasi antisipatif serta persepsi mengenai whistleblowing dan whistleblowing intention antara mahasiswa akuntansi bidikmisi dan non-bidikmisi Universitas Malikussaleh. 


\section{Whistleblowing}

(Efendi, 2009: 224) didalam (Hardianto et al, 2017) mengatakan bahwa whistleblowing adalah pengungkapan tindakan pelanggaran atau perbuatan yang melawan hukum yang dapat merugikan perusahaan atau organisasi maupun pemangku kepentingan, yang disampaikan oleh pihak internal atau eksternal kepada pemimpin perusahaan yang selanjutnya dapat dilakukan tindakan atas pelanggaran tersebut. Dijelaskan pula oleh (Hardianto et al, 2017) bahwa whistleblowing dilakukan dengan melihat seberapa besar keseriusan dari sebuah kasus, tanggung jawab pelapor dalam melaporkan kasus kecurangan dan menganalisa kerugian yang ditimbulkan dari tindakan kecurangan tersebut.

Didalam sebuah organisasi atau perusahaan. Menurut (Setiyawan, 2016) untuk mengukur variabel whistleblowing maka digunakan dua aspek yaitu persepsi mengenai whistleblowing (terdiri dari tiga faktor (keseriusan, tanggung jawab, dan resiko) dan whistleblowing intention. Dimana:

1. Persepsi whistleblowing, suatu persepsi terhadap keseriusan tindakan, tanggung jawab untuk melaporkan pelanggaran dan dampak negatif yang akan diterima sebagai akibat pelaporan tersebut.Tingkat keseriusan merupakan tindakan yang dinilai dengan mempertimbangkan besarnya pelanggaran sosial yang dilakukan pada masing-masing kasus. Tingkat tanggung jawab untuk melaporkan pelanggaran dinilai dengan mempertimbangkan apakah pelaporan tindakan yang diragukan tersebut merupakan suatu tugas karyawan sebagai bagian dari perusahaan ataukah justru kewajiban pribadi. Resiko merupakan tanggung jawab untuk melaporkan pelanggaran dan dampak negatif yang akan diterima sebagai akibat pelaporan tersebut.

2. Keinginan untuk melakukan whistleblowing merupakan salah satu bentuk dari keseriusan seseorang dalam suatu situasi.

\section{Komitmen Profesional}

Menurut (Tranggono \& Andi, 2008) dalam (Setiyawan, 2016) mengatakan bahwa, komitmen profesional adalah tingkat loyalitas individu terhadap profesi yang sedang dijalaninya sekarang, seperti yang telah dipersepsikan oleh individu tersebut. Supaya seseorang dapat berperilaku dengan baik, maka ia harus mematuhi etika profesional yang telah diatur dalam kode etik. Didalam pekerjaan ditekankan akan adanya komitmen profesi yang tinggi, sehingga diharapkan akan memudahkan perusahaan dalam meraih cita-cita dan tujuan yang telah ditentukan oleh perusahaan.

Komitmen profesional dapat diukur dengan faktor yang dijelaskan oleh (Dwyer et al, 2000) dalam (Setiyawan, 2016) yang menganggap komitmen profesional sebagai model satu faktor yaitu komitmen profesional afektif. Komitmen profesional terdiri dari beberapa indikator yaitu, melakukan usaha luar biasa yang melebihi harapan, bangga terhadap profesi akuntansi, patuh terhadap peraturan profesi, peduli dengan citra profesi akuntansi, dan bersedia pada profesi tersebut selama mampu melakukanya.

Jadi, dapat disimpulkan komitmen profesional adalah suatu loyalitas atau kesetiaan seorang individu terhadap profesi yang sedang dijalaninya dalam sebuah perusahaan atau organisasi. Dengan adanya komitmen profesi yang tinggi, sehingga diharapkan akan memudahkan perusahaan dalam meraih cita-cita dan tujuan yang telah ditentukan oleh perusahaan.

\section{Hubungan Komitmen Profesional terhadap Whistleblowing}

Dari penjelasan diatas apabila melihat hubungan antara komitmen profesional terhadap whistleblowing serta whistleblowing intention dapat kita lihat dari penjelasan The Accounting Change Commision (AECC) dalam (Elias, 2008) yang mengatakan bahwa, semakin tinggi tingkat komitmen profesional seseorang maka, semakin kecil kemungkinan mereka meninggalkan profesi yang digelutinya dan mempengaruhi anggapannya mengenai pentingnya melaporkan tindakan mencurigakan. Maka disimpulkan bahwa semakin tinggi level komitmen profesional seseorang maka semakin tinggi anggapan bahwa whistleblowing adalah sesuatu yang penting dan meningkatkan keinginan seseorang untuk melakukan whistleblowing (whistleblowing intention).

Hal tersebut sejalan dengan hasil penelitian yang dilakukan oleh (Setiyawan, 2016) dengan judul Analisis Perbedaan Komitmen Profesional dan Sosialisasi Antisipatif Mahasiswa Udinus dan Unika Soegijapranata Pada Hubungannya dengan Whistleblowing. Hasil penelitian ini menunjukan bahwa, variabel komitmen profesional mahasiswa akuntansi UDINUS dan UNIKA Soegijapranata berpengaruh positif terhadap persepsi mereka akan pentingnya whistleblowing dan keinginan mereka untuk melakukan whistleblowing (whistleblowing intention). Pada tingkat signifikansi masing-masing sebesar 0,027 dan 0,001. Artinya bahwa semakin tinggi tingkat komitmen profesional semakin kecil kemungkinan mereka meninggalkan profesi yang digelutinya dan mempengaruhi anggapannya mengenai pentingnya melaporkan tindakan mencurigakan. Maka disimpulkan bahwa dengan tingginya tingkat komitmen profesional maka semakin tinggi pula kemungkinan seseorang untuk melakukan whistleblowing.

\section{Sosialisasi Antisipatif}

Menurut (Merdikawati, 2012) dalam (Setiyawan, 2016) mengatakan bahwa, sosialisasi antisipatif adalah pemahaman seseorang mengenai sikap dan kepercayaan profesi yang sedang dijalani. 
Dengan adanya sosialisasi antisipatif, maka seseorang dapat mengetahui tindakan-tindakan apa saja yang boleh dan tidak boleh dilakukan dalam profesi yang sedang dilakukannya sekarang. Sedangkan menurut Elias dalam (Hardianto et al, 2017) Sosialisasi antisipatif memiliki makna yaitu suatu proses penyesuaian diri dan keyakinan yang berasal dalam diri seseorang sebelum mereka memasuki lingkungan baru sejak masih dalam tahap pendidikan. Lingkungan baru ini salah satunya yaitu lingkungan kerja.

Dalam (Setiyawan, 2016) juga menyebutkan untuk mengukur tingkat sosialisasi antisipatif maka menggunakan empat faktor yaitu, misstatement, disclosure, cost-benefit dan responsibility. Dimana, misstatement merupakan suatu keinginan seseorang melaporkan keuangan secara tidak tepat, disclosure, merupakan suatu ukuran kepercayaan seseorang bahwasanya perusahaan harus mengungkapkan informasi yang lebih kepada pengguna laporan keuangan, Cost-benefit, merupakan indikasi keyakinan seseorang bahwa pelaporan keuangan jauh lebih memiliki manfaat daripada biaya yang harus dibayar. Responsibility, merupakan indikasi keyakinan seseorang bahwa manajer bertanggungjawab atas keakuratan pelaporan.

\section{Hubungan Sosialisasi Antisipatif terhadap Whistleblowing.}

Dari penjelasan diatas apabila melihat hubungan sosialisasi antisipatif terhadap whistleblowing serta whistleblowing itention maka, (Elias, 2006) dalam (Pangesti \& Rahayu, 2017) menemukan bahwa sosialisasi antisipatif merupakan determinan yang penting bagi pembentukan persepsi yang baik kepada mahasiswa terhadap pentingnya laporan keuangan dan menimbulkan keinginan untuk tetap patuh kepada etika dalam profesinya dan pentingnya pembelajaran mengenai sosialisasi antisipatif sejak dini terutama pada mahasiswa akuntansi mengenai laporan keuangan akan berpengaruh besar pada profesinya dalam kelompok atau organisasi dimasa datang, yang berkaitan dengan pelaporan tindak kecurangan atau whistleblowing.

Artinya bahwa, semakin intens sosialisasi pada mahasiswa akuntansi tentang pentingnya laporan keuangan akan membentuk penilaian positif terhadap profesi akuntan yang akan mempengaruhi sikap etis mereka dalam memyelesaikan konflik profesionalnya dan semakin tinggi pula kemungkinan mereka untuk melakukan whistleblowing. Hal tersebut sejalan dengan penelitian yang dilakukan oleh (Pangesti \& Rahayu, 2017) dengan judul Pengaruh Komitmen Profesional dan Sosialisasi Antisipatif Mahasiswa Akuntansi Terhadap Whistleblowing (Studi Empiris pada Mahasiswa Akuntansi Universitas Telkom Di Bandung Tahun Akademik 2015/2016).

Dalam penelitian tersebut menunjukan bahwa, menunjukan secara parsial sosialisasi antisipatif berpengaruh secara signifikan dengan arah positif terhadap whistleblowing pada mahasiswa S1 akuntansi Universitas Telkom tahun akademik 2015/2016. Artinya adalah semakin tinggi tingkat sosialisasi antisipatif seseorang maka, semakin tinggi tingkat kemampuan seseorang untuk mengetahui tindakan-tindakan apa saja yang boleh dan tidak boleh dilakukan dalam profesi yang sedang dijalaninya. Maka, disimpulkan bahwa dengan tingginya tingkat sosialisasi antisipatif maka semakin tinggi pula kemungkinan seseorang untuk melakukan whistleblowing.

\section{Kerangka Konseptual}

Adapun kerangka konseptual dalam penelitian ini adalah sebagai berkut:

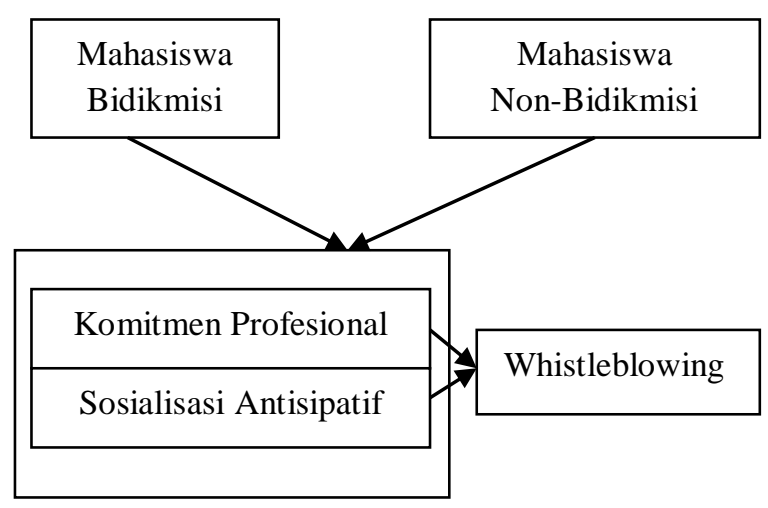

Gambar 1 Kerangka Konseptual

\section{METODE PENELITIAN \\ Lokasi dan obyek penelitian}

Objek dalam penelitian ini adalah mahasiswa akuntansi (Bidikmisi dan Non-Bidikmisi) Universitas Malikussaleh tahun akademik 2020-2021. Lokasi dalam penelitian ini adalah Fakultas Ekonomi dan Bisnis Jurusan Akuntansi Universitas Malikussaleh jalan Kampus Bukit Indah, Blang Pulo Lhokseumawe, Telepon (0645) 7010381-7010385, Fax (0645) 44450.

\section{Populasi}

populasi dalam penelitian saya ini adalah seluruh mahasiswa akuntansi (Bidikmisi dan Non Bidikmisi) Universitas Malikussaleh tahun akademik 2020-2021 yang telah mengambil mata kuliah Etika profesi dan Auditing I. Pertimbangan pemilihan populasi mahasiswa akuntansi yang telah mengambil kedua matakuliah tersebut karena, pada matakuliah tersebut materi mengenai tentang etika mulai diberikan dan juga diperkenalkan dengan berbagai skandal yang terjadi didalam maupun diluar negeri. Serta mahasiswa merupakan semester 6 dan 8. Yang berjumlah 286 mahasiswa (143 bidikmisi dan 125 mahasiswa non-bidikmisi). 


\section{Sampel}

Agar jumlah sampel lebih representatif terhadap jumlah populasi digunakan rumus Slovin yang menggunakan nilai kritis atau batas ketelitian sebesar 0,1. Rumus tersebut adalah :

$$
\mathrm{n}=\frac{\mathrm{N}}{1+\mathrm{Ne}^{2}}=\frac{268}{1+\left(268 \times 0.1^{2)}\right)}=85,85
$$

Berdasarkan perhitungan pada rumus yang digunakan, maka data diketahui jumlah sampel yang akan digunakan adalah sebanyak 85,85 yang dibulatkan menjadi 90 maka masing masing kelompok mahasiswa akuntansi (Bidikmisi dan NonBidikmisi) sebanyak 45 mahasiswa.

\section{Teknik pengumpulan data}

Penelitian ini menggunakan data primer yaitu sumber data penelitian yang diperoleh secara langsung dari sumber aslinya yang berupa pertanyaanpertanyaan yang mengacu pada kuesioner dari individu atau kelompok (orang) maupun hasil observasi dari suatu obyek, kejadian atau hasil pengujian (benda). Dengan kata lain, peneliti membutuhkan pengumpulan data dengan cara menjawab pertanyaan riset (metode survei) atau penelitian benda (metode observasi).
a. Kuesioner (Angket)
b. Dokumentasi

\section{HASIL PENELITIAN DAN PEMBAHASAN}

\section{Gambaran Umum}

Universitas Malikussaleh didirikan dengan mengambil nama besar raja kerajaan Samudera Pasai pertama, yang dilandasi pada semangat estafet kepemimpinan dan pembangunan yang telah diletakannya melalui sifat kepelaporan, kedinamisan, serta patriotismenya Sultan Malikussaleh. Kerajaan Islam Samudera Pasai dalam sejarah tercatat sebagai Kerajaan Islam pertama di Nusantara yang menjadi cikal bakal pusat pengembangan dan penyebaran agama Islam di kawasan Nusantara dan Asia Tenggara, merupakan pusat Pendidikan Islam dan Ilmu Pengetahuan ternama yang mewariskan semangat pejuang bagi generasi penerusanya dalam mengembangkan agama Islam, ilmu pengetahuan, teknologi, seni, dan budaya yang telah menghasilkan Syekh (Guru Besar) dan ilmunya lainya.

Universitas Malikussaleh juga merupakan salah satu dari sepuluh Universitas terbanyak di Indonesia dalam menerima mahasiswa beasiswa bidikmisi sejak tahun 2016 hingga tahun 2020 ini. Universitas Malikussaleh terdiri dari beberapa Fakultas salah satunya yaitu Fakultas Ekonomi dan Bisnis. Pendirian Fakultas Ekonomi dan Bisnis sudah dirintas sejak tahun 1986, dengan dikeluarkan SK Yayasan Pendidikan

Malikussaleh
No.029/SK/YPM/1986 tentang pengankatan dekan a.n Drs. M. Hasan Usman. Atas surat keputusan tersebut, Fakultas Ekonomi Universitas Malikussaleh sudah mulai melaksanakan pendidikan sejak tahun 1986. Fakultas Ekonomi juga telah membuka beberapa program studi baru salah satunya ialah program studi Akuntansi

Latar belakang berdirinya Prodi Akuntansi Fakultas Ekonomi dan Bisnis didirikan pada tahun 2007 dengan memiliki 2 kelas dan bertempat di Bukit Indah, Lhokseumawe, Aceh. Prodi akuntansi memiliki tujuan untuk menghasilkan sarjana akuntansi yang siap pakai, baik untuk intansi pemerintah, swasta, maupun pihak lain. Serta menghasilkan sarjana akuntansi yang memiliki daya saing yang mampu meningkatkan mutu pendidikan dan pengabdian secara berkesinambungan dan memberikan pendidikan kesarjanaan yang berkualitas tinggi untuk mendukung kebutuhan lulusan dalam melanjutkan pendidikan profesi akuntan dan lanjutan pendidikan strata 2 dan 3.

\section{Uji Kualitas Data}

\section{Uji Reabilitas}

Tabel 1

Hasil Uji Reabilitas

\begin{tabular}{|l|c|c|}
\hline \multicolumn{1}{|c|}{ Instrumen } & $\begin{array}{c}\text { Reliabilitas } \\
(\text { Alpha) }\end{array}$ & $\begin{array}{c}\text { Keteranga } \\
\text { n }\end{array}$ \\
\hline Whistleblowing (Y) & 0,861 & Reliabel \\
\hline $\begin{array}{l}\text { Komitmen } \\
\text { Profesional (X1) }\end{array}$ & 0,797 & Reliabel \\
\hline $\begin{array}{l}\text { Sosialisasi } \\
\text { Antisipatif (X2) }\end{array}$ & 0,780 & Reliabel \\
\hline
\end{tabular}

Berdasarkan tabel diatas dapat dilihat bahwa variabel independen yaitu komitmen profesional (X1) dan sosialisasi antisipatif (X2) dapat dikatakan reliabel karena nilai alpha kedua variabel tersebut lebih dari 0,60 yaitu 0,86 dan 0,79. Sedangkan untuk variabel dependen yaitu whistleblowing (Y) juga dapat dikatakan reliabel karena nilai alpha variabel tersebut diatas 0,60 yaitu 0,78 .

\section{Uji Validitas}

Tabel 2

Hasil Uji Validitas Variabel Whistleblowing

\begin{tabular}{|c|c|c|c|}
\hline $\begin{array}{c}\text { Item } \\
\text { pertanyaan }\end{array}$ & $\begin{array}{c}\text { Corrected } \\
\text { item-Total } \\
\text { Correlation } \\
\text { (r-hitung) }\end{array}$ & $\mathrm{r}$ - tabel & Hasil \\
\hline 1 & 0,547 & 0,207 & Valid \\
\hline 2 & 0,493 & 0,207 & Valid \\
\hline 3 & 0,391 & 0,207 & Valid \\
\hline 4 & 0,456 & 0,207 & Valid \\
\hline 5 & 0,322 & 0,207 & Valid \\
\hline 6 & 0,622 & 0,207 & Valid \\
\hline 7 & 0,486 & 0,207 & Valid \\
\hline
\end{tabular}




\begin{tabular}{|c|c|c|c|}
\hline 8 & 0,540 & 0,207 & Valid \\
\hline 9 & 0,576 & 0,207 & Valid \\
\hline 10 & 0,529 & 0,207 & Valid \\
\hline 11 & 0,586 & 0,207 & Valid \\
\hline 12 & 0,405 & 0,207 & Valid \\
\hline
\end{tabular}

Hasil analisis dari tabel diatas menunjukan bahwa dari segi ketepatan dalam mengukur, seluruh pertanyaan dan pernyataan yang digunakan dalam mengukur variabel whistleblowing (Y) memiliki ketepatan yang baik ini terlihat dari besarnya koefesien validitas yang dihasilkan oleh setiap item pertanyaan dan penyataan yang semuannya diatas 0,207 atau bisa dikatakan bahwa $r$ hitung $>r$ kritis ( $r$ tabel), sehingga dapat disimpulkan bahwa semua pertanyaan untuk variabel whistleblowing (Y) adalah valid.

\section{Uji Asumsi Klasik}

\section{Uji Normalitas}

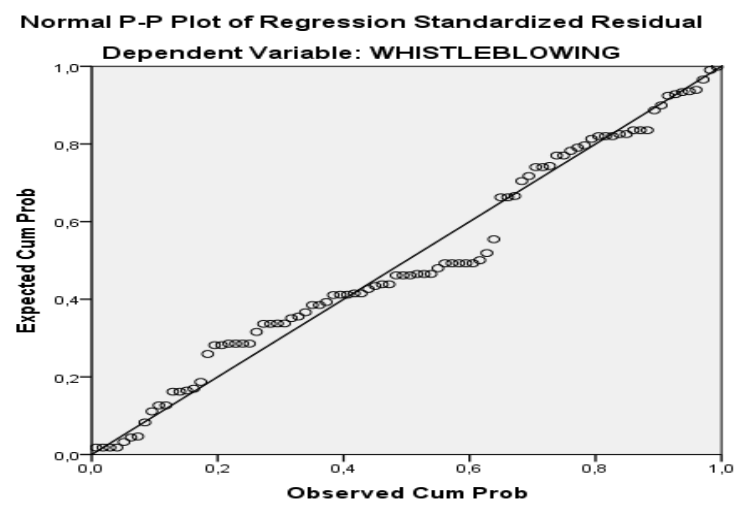

Gambar 2

Hasil Uji Normalitas

Berdasarakan Gambar 2 grafik normal plot, menunjukan bahwa model regresi layak dipakai dalam penelitian ini karena grafik normal plot terlihat titiktitik menyebar disekitar garis diagonal serta penyebaran mengikuti garis diagonal menunjukan pola distribusi normal, sehingga model regresi memenuhi asusmsi normalitas.

\section{Uji Multikulinearitas}

Tabel 3

Hasil Uji Multikolinearitas

\begin{tabular}{|c|c|c|c|}
\hline \multirow[b]{2}{*}{ Model } & \multirow[b]{2}{*}{ Sig. } & \multicolumn{2}{|c|}{ Collinearity Statistics } \\
\hline & & Tolerance & VIF \\
\hline (Constant) & 000 & & \\
\hline KOMITMEN PROFESIONAL &, 111 & ,716 & 1,397 \\
\hline SOSIALISASI ANTISIPATIF &, 000 & ,716 & 1,397 \\
\hline
\end{tabular}

Hasil pengujian menunjukan bahwa semua variabel yang digunakan sebagai predictor model regresi menunjukan nilai VIF yang cukup kecil, dimana semua berada dibawah 10 yaitu 1,397 dan nilai tolerance lebih kecil dari 0,10 yaitu 0,716 . Hal ini berarti bahwa veriabel-variabel bebas yang digunakan dalam penelitian ini tidak menunjukan adanya gejala multikoleniaritas.

\section{Uji Heterokedastisitas}

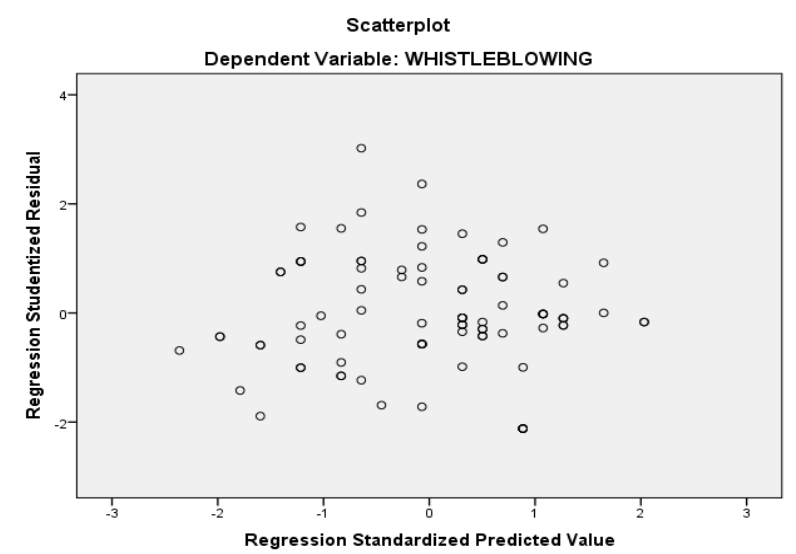

Gambar 3

Hasi Uji Heterokedastisitas

Melalui pengamatan grafik di atas dapat dilihat bahwa titik-titik menyebar secara acak dan tidak menunjukkan pola tertentu. Titik-titik tersebut tersebar di atas dan di bawah angka 0 pada sumbu $\mathrm{Y}$. Dari hasil tersebut dapat disimpulkan bahwa kedua model regresi tidak mengandung gejala heteroskedastisitas.

\section{Hasil Pengujian Hipotesis Hasil Uji Parsial (Uji t)}

Tabel 4 Hasil Pengujian Hipotesis

\begin{tabular}{|c|c|c|c|c|}
\hline \multirow[b]{2}{*}{ Model } & \multicolumn{2}{|c|}{$\begin{array}{c}\text { Unstandardized } \\
\text { Coefficients }\end{array}$} & \multirow{2}{*}{$\begin{array}{c}\begin{array}{c}\text { Standar } \\
\text { dized } \\
\text { Coeffici } \\
\text { ents }\end{array} \\
\text { Beta }\end{array}$} & \multirow[b]{2}{*}{$\mathrm{t}$} \\
\hline & $B$ & Std. Error & & \\
\hline (Constant) & 37,582 & 7,204 & & 5,216 \\
\hline KOMITMEN & & & & \\
\hline $\begin{array}{l}\text { PROFESIONA } \\
\mathrm{L}\end{array}$ &,- 614 & , 381 &,- 189 & $1,612^{-}$ \\
\hline $\begin{array}{l}\text { SOSIALISASI } \\
\text { ANTISIPATIF }\end{array}$ & ,614 & , 161 & ,447 & 3,813 \\
\hline
\end{tabular}

Dari hasil perhitungan dalam tabel di atas dapat dilihat bahwa pada variabel independen yaitu komitmen profesional (X1) yang dimasukkan ke dalam model regresi memiliki signifikansi di atas 0,05 Yaitu 0,111. Sedangkan pada variabel independen lainya yaitu sosialisasi antisipatif (X2) yang 
dimasukkan ke dalam model regresi memiliki signifikansi di bawah 0,05 yaitu 0,000. Jadi dapat disimpulkan bahwa komitmen professional tidak berpengaruh terhadap whistleblowing. Sedangkan sosialisasi antisipatif ditunjuk berpengaruh positif terhadap whistleblowing.

\section{Koefesiensi Determinasi (Adjusten-R)}

Tabel 5

Hasil Koefesiensi Determinasi

\begin{tabular}{l|r|r|r|l|}
\hline & & $\mathrm{R}$ & Adjusted & Std. Error of \\
Model & $\mathrm{R}$ & Square & R Square & the Estimate \\
\hline 1 &, $381^{\mathrm{a}}$ &, 145 &, 126 & 7,885 \\
\hline
\end{tabular}
a. Predictors: (Constant), SOSIALISASI ANTISIPATIF,
KOMITMEN PROFESIONAL

Dari tampilan output SPSS model summary, besarnya adjusted $R$ squared adalah 0,126 , hal ini berarti $12,6 \%$ variasi whistleblowing dapat dijelaskan oleh variasi kedua variabel independen KP (komitmen professional) dan SA (sosialisasi antisipatif). Sedangkan standard error of the estimate dari data tersebut sebesar 7,885. Nilai dari data tersebut relatif lebih rendah jika dibanding dengan data yang bersifat runtun waktu (time series). Hal tersebut dikarenakan adanya variasi yang besar antara masing-masing pengamatan.

(Ghozali, 2005) mengatakan bahwa koefisien determinasi bukan satu-satunya kriteria untuk memilih model yang baik. Selain koefisien determinasi, model harus sesuai dengan teori ekonomika dan lolos dari uji asumsi klasik. Model regresi dalam penelitian ini telah memenuhi semua uji asumsi klasik, jadi dapat dikatakan model penaksir dalam penelitian ini merupakan model penaksir yang baik untuk dijadikan model empirik.

\section{Hasil Uji Beda (Independent Sample T-test)}

Tabel 6

Hasil Uji Beda Independen Sample T-test

\begin{tabular}{|l|c|c|c|c|}
\hline \multirow{2}{*}{ Variabel } & \multicolumn{2}{|c|}{ Levene's Test } & \multicolumn{2}{c|}{$T$ - test } \\
\cline { 2 - 5 } & $\mathrm{F}$ & Sig. & $\mathrm{T}$ & $\begin{array}{c}\text { Sig. (2 } \\
\text { tailed) }\end{array}$ \\
\hline $\begin{array}{l}\text { Komitmen } \\
\text { Profesional }\end{array}$ & 3,930 & 0,041 & $-8,129$ & 0,000 \\
\hline $\begin{array}{l}\text { Sosialisasi } \\
\text { Antisipatif }\end{array}$ & 0,377 & 0,541 & $-1,430$ & 0,156 \\
\hline
\end{tabular}

Dilihat dari tabel 6, indikator komitmen professional (X1) memiliki F hitung Levene test sebesar 3,930 dengan probabilitas 0,041. Karena di bawah 0,05 maka memiliki varians yang berbeda.
Untuk itu uji beda t-test harus menggunakan asumsi equal variances not assumed. Dari output SPSS didapatkan nilai t sebesar -8,129 dengan signifikansi 0,000 (two-tailed). Hal tersebut mengindikasikan bahwa rata-rata tingkat komitmen profesional mahasiswa Bidikmisi dan Non-Bidikmisi mamiliki atau terdapat perbedaan yang signifikan, berarti H3 diterima atau hipotesis 3 dapat diterima dan dapat dikatakan bahwa tingkat komitmen profesional mahasiswa bidikmisi dan Non-bidikmisi Universitas malikussaleh memiliki rata-rata yang berbeda.

Indikator sosialisasi antisipatif (X2) memiliki

F hitung Levene test sebesar 0,377 dengan probabilitas 0,541. Karena di atas 0,05 maka memiliki varians yang sama. Untuk itu uji beda t-test harus menggunakan asumsi equal variances not assumed. Dari output SPSS didapatkan nilai t sebesar -1,430 dengan signifikansi 0,156 (two-tailed). Hal tersebut mengindikasikan bahwa rata-rata tingkat sosialisasi antisipatif mahasiswa bidikmisi dan Non-bidikmisi tidak terdapat perbedaan yang signifikan, berarti H4 ditolak atau hipotesis 4 tidak dapat diterima dan dapat dikatakan bahwa tingkat sosialisasi antisipatif mahasiswa bidikmisi dan Non-bidikmisi Universitas malikussaleh tidak memiliki perbedaan atau sama.

\section{Pembahasan Hasil Penelitian \\ 1. Pengaruh Komitmen Profesional $\left(\mathbf{X}_{1}\right)$ Terhadap Whistleblowing (Y)}

Hasil uji secara parsial (uji t) pada variabel komitmen profesional (X1) memiliki signifikansi di atas 0,05 yaitu 0,111. Dengan demikian, dapat dikatakan bahwa komitmen profesional (X1) tidak berpengaruh terhadap whistleblowing. Hal ini juga menunjukan bahwa tingkat komitmen profesional mahasiswa akuntansi yang bidikmisi maupun yang non-bidikmisi Universitas Malikussaleh tidak mempengaruhi persepsi dan keinginan mereka untuk melakukan whistleblowing.

Hal ini terjadi karena, mahasiswa akuntansi baik yang bidikmisi maupun yang non-bidikmisi tidak memiliki komitmen profesional dan melakukan kecurangan atau tidak tertarik pada whistleblowing (tindakan pengungkapan kecurangan). Ketidak komitmenan mahasiswa Universitas Malikussaleh karena sebagaimana kita ketahui bahwasanya 50\% dari mahasiswa akuntansi dalam penelitian ini adalah mahasiswa bidikmisi. Yang mana beasiswa bidikmisi seperti yang kita ketahui selain mengeratiskan biaya uang kuliah tunggal mahasiswa (UKT), mahasiswa bidikmisi disini juga di berikan uang tambahan atau uang saku. Dengan banyaknya beasiswa yang diberikan oleh pihak bidikmisi, membuat mahasiswa akuntansi bidikmisi Universitas Malikussaleh terlena dan lupa akan kewajiban mereka atau kekomitmenan mereka terhadap apa yang mereka jalani yaitu mahasiswa bidikmisi, yang seharusnya mempertahankan nilai mereka di bidang akademik 
agar kedepannya mereka tidak kehilangan beasiswa tersebut.

\section{Pengaruh Sosialisasi Antisipatif $\left(\mathbf{X}_{2}\right)$ Terhadap Whistleblowing (Y)}

Hasil uji secara parsial (uji t) pada variabel sosialisasi antisipatif $\left(\mathrm{X}_{2}\right)$ memiliki signifikansi di bawah 0,05 yaitu 0,000. Dengan demikian, dapat dikatakan bahwa sosialisasi antisipatif $\left(\mathrm{X}_{2}\right)$ berpengaruh terhadap whistleblowing. Hal juga ini menunjukan bahwa tingkat sosialisasi antisipatif mahasiswa akuntansi yang bidikmisi maupun yang bidikmisi Universitas Malikussaleh mempengaruhi persepsi dan keinginan mereka untuk melakukan whistleblowing.

Hal tersebut terjadi Karena sebagaimana dikatahui bahwa pihak bidikmisi Universitas Malikussaleh memang sudah baik dalam memberikan pelatihan softskill setiap tahunya kepada seluruh mahasiswa bidikmisi Universitas Malikussaleh, tentunya mahasiswa akuntansi juga turut mengikuti acara tersebut. dengan adanya pelatihan softskill ini, rasa atau tingkat sosialisasi antisipatif seseorang tertanam sejak dini. Karena telah tertanamnya sosialisasi antisipatif tersebut pada mahasiswa bidikmisii Universitas Malikussaleh akuntansi khususnya, maka diindikasikan menjadi penyebab rendahnya keinginan mahasiwa melakukan kecurangan dan meningkatkan keinginan mereka melakukan whistleblowing.

\section{Perbedaan Tingkat Komitmen Profesional Mahasiswa Akuntansi Bidikmisi dan Non- Bidikmisi Universitas Malikussaleh \\ Pada hasil uji beda Independen sample t-test} pada variabel komitmen profesional menunjukan ada perbedaan yang signifikan antara mahasiswa akuntansi bidikmisi dan non-bidikmisi Universitas Malikusaaleh. Yaitu memiliki nilai signifikan dibawah 0,05 atau 0,041 dan juga pada standar deviasi mahasiswa bidikmisi dan non-bidikmisi terdapat perbedaan yang mana, mahasiswa non-bidikmisi memiliki tingkat standar deviasi lebih tinggi yaitu 2,797 dibandingkan mahasiswa bidikmisi yaitu 2.168. Hal tersebut terjadi indikasikan karena beberapa hal.

Hal yang diindikasikan menjadi penyebab terjadinya perbedaan tingkat komitmen profesional antara mahasiswa bidikmisi dan non-bidikmisi Universitas Malikussaleh ini, dikarenakan kedua karakteristik mahasiswa tersebut berasal dari latar belakang keluarga dan ekonomi yang berbeda sehingga pola pikir kedua karakteristik mahasiswa tersebut juga berbeda dan memepengaruhi pandangan mereka tentang pentingnya komitmen profesional.

Seperti jug halnya mahasiswa non-bidikmisi akuntansi Universitas Malikussaleh yang tidak mendapatkan beasiswa seperti yang didapatkan oleh mahasiswa akuntansi yang bidikmisi, kerena tidak mendapatkan beasiswa dan harus membiayai kuliah dengan anggaran pribadi. Sehingga membuat mahasiswa akuntansi yang non-bidikmisi ini lebih berkomitmen sebagai mahasiswa akuntansi Universitas Malikussaleh dengan lebih giat belajar untuk mendapatakan nilai indek prestasi akademik yang tinggi. Dengan tingginya nilai indek prestasi akademik mahasiswa tersebut sehingga membuka peluang bagi mereka untuk mendapatkan beasiswabeasiswa lainya. Jadi dapat disimpulakn penyebab terjadinya perbedaan tingkat komitmen profesional mahasiswa akuntansi bidikmisi dan non bidikmisi Universitas Malikussaleh yaitu keadaan kedua karakter mahasiswa dan situasi yang sedang dijalani oleh masiswa tersebut.

\section{Perbedaan Tingkat Sosialisasi Antisipatif Mahasiswa Akuntansi Bidikmisi dan Non- Bidikmisi Universitas Malikussaleh \\ Pada hasil uji beda Independen sample t-test} pada variabel sosialisasi antisipatif menunjukan tidak terdapat perbedaan yang signifikan antara mahasiswa akuntansi bidikmi dan non-bidikmisi Universitas Malikusaaleh. Yaitu memiliki nilai signifikan diatas 0,05 atau 0,156 dan juga pada standar deviasi mahasiswa bidikmisi dan non-bidikmisi juga memiliki jumlah yang sama.

Hal ini terjadi indikasikan bahawa walaupun mahasiswa bidikmisi mendapatkan pelatihan softskill setiap tahunya sehingga dapat meningkatkan tingkat sosialisi antisipatif mereka sebelum mereka memasuki dunia kerja. Tetapi, untuk mahasiswa yang nonbidimisi juga tidak kalah dengan mahasiswa bidikmisi, yang mana mahasiswa non-bidikmisi aktiv dalam meningkatkan sosalisasi antisipatif mereka melalui media lain yang berbeda dari bidikmisi yang ditawarkan oleh UNIMAL hal tersebut sejalan dengan hasil yang didapat oleh seorang peneliti yang meneliti tentang komitmen dan sosialisasi antisipatif mahasiswa pada hubungannya dengann whistleblowing. Yaitu (Malik, 2010) yang menyatakan bahwa terdapat perbedaan tingkat komitmen profesional antar mahasiswa pada hubungannya dengan whistleblowing.

\section{PENUTUP}

\section{Kesimpulan}

1. Hasil uji secara parsial (uji t) pada variabel komitmen profesional (X1) memiliki signifikansi di atas 0,05 yaitu 0,111 . Dengan demikian, dapat dikatakan bahwa komitmen profesional (X1) tidak berpengaruh terhadap whistleblowing $(\mathrm{Y})$.

2. Tetapi, hasil yang berbeda dintunjukan oleh variabel Sosialisasi Antisipatif (X2)) yaitu Hasil uji secara parsial (uji t) pada variabel 
sosialisasi antisipatif (X2) memiliki signifikansi di bawah 0,05 yaitu 0,000 . Dengan demikian, dapat dikatakan bahwa sosialisasi antisipatif (X2) berpengaruh terhadap whistleblowing $(\mathrm{Y})$.

3. Berdasarkan hasil pembahasan menunjukan bahwa hasil dari uji Independent sampel $T$ test menunjukan hasil bahwa pada tingkat Komitmen Profesional (X1) didapatkan nilai memiliki F hitung Levene test sebesar 3,930 dengan probabilitas 0,041 . Karena di bawah 0,05 maka memiliki varians yang berbeda. Untuk itu uji beda t-test harus menggunakan asumsi equal variances not assumed. Dari output SPSS didapatkan nilai $\mathrm{t}$ sebesar 8,129 dengan signifikansi 0,000 (two-tailed). Hal tersebut mengindikasikan bahwa ratarata tingkat komitmen profesional mahasiswa akuntansi Bidikmisi dan Bidikmisi Universitas Malikussaleh terdapat perbedaan tingkat komitmen profesional (X1) yang signifikan antara mahasiswa akuntansi yang bidikimisis dan mahasiswa akuntansi yang non-bidikmisi Univesitas Malikussaleh.

4. Pada sosialisasi antisipatif (X2) memiliki F hitung Levene test sebesar 82,135 dengan probabilitas 0,377. Karena di atas 0,05 maka memiliki varians yang sama. Untuk itu uji beda $t$-test harus menggunakan asumsi equal variances not assumed. Dari output SPSS didapatkan nilai $\mathrm{t}$ sebesar -1430 dengan signifikansi 0,156 (two-tailed). Hal tersebut mengindikasikan bahwa rata-rata tingkat sosialisasi antisipatif (X2) mahasiswa bidikmisi dan Non-bidikmisi tidak terdapat perbedaan yang signifikan antara mahasiswa akuntansi yang bidikimisi dan mahasiswa akuntansi yang non-bidikmisi.

\section{Saran}

Hasil menyatakan komitmen profesional tidak berpengaruh terhadap whistleblowing mahasiswa akuntansi (bidikmisi dan non-bidikmisi) Universitas Malikussaleh dan variabel sosialisasi antisipatif berpengaruh positif terhadap whistleblowing mahasiswa akuntansi (bidikmisi dan non-bidikmisi) Universitas Malikussaleh serta pada tingkat komitmen profesional terdapat perbedaan yang signifikan. Tetapi, pada tingkat sosialisasi antisipatif tidak terdapat perbedaan yang signifikan antara mahasiswa akuntansi (bidikmisi dan nonbidikmisi) Universitas Malikussaleh.

Maka perlu adanya analisa dan tidak lanjut mengenai komitmen profesional dengan demikian peneliti akan memberikan beberapa saran untuk penelitian selanjutnya:
1. Menambah jumlah responden dan wilayah penelitian sehingga menambah sebuah penelitian yang lebih baik.

2. Menambahkan jumlah variabel independen yang dapat mempengaruhi whistleblowing seperti locus of control, teknologi informasi dan budaya yang berbeda.

3. Tidak hanya menggunakan kuesioner tetapi juga melakukan wawancara secara langsung.

\section{DAFTAR PUSTAKA}

Adri, R., Surya, S., Zarefar, A., \& Mela, N. F. (2017). Accounting and Finance Review Whistle Blowing in The Police Sector: The Importance of Control Behaviour Factor and Professional Commitment. Journal of Accounting 2(2), 9-14.

Ahmad, S. (2012). Internal Whistle-Blowing Intentions: A Study of Demographic and Individual Factors. Journal of Modern Accounting and Auditing, 8(11), 1632-1645. http://ro.ecu.edu.au/ecuworks2012/638.

Aridyanti, E. P. (2019). Persepsi Mahasiswa Akuntansi Tentang Keinginan Untuk Melakukan Whistleblowing ( Studi Empiris Pada Mahasiswa Akuntansi Universitas Muhammadiyah Surakarta ). Jurnal Akuntansi. Ekonomi Dan Bisnis, 1-11.

Bakar, F. D. (2019). Pengaruh Komitmen Profesional, Locus of Control dan Sosialisasi Antisipatif Mahasiswa Terhadap Whistleblowing. Jurnal Akuntansi, 08(01), 1-13.

Chomsyatun, S. (2018). Pengaruh Pemberian Beasiswa Bidikmisi terhadap Motivasi Berprestasi Mahasiswa Ditinjau dari Prespektif Ekonomi Islam.Skripsi. Universitas Islam Negeri Radien Intan Lampung.

Efendi, M. A. (2009). The Power of Good Corporate Governance teori dan Implementasi. Jakarta: Salemba Empat.

Ghozali. (2005). Aplikasi Analisis Multivariate dan Program SPSS. Semarang: Badan Penerbit Universitas Diponegoro.

Hardianto. R, Nur Hidayati, dan J. (2017). Analisis Komitmen Profesional dan Sosialisasi Antisipatif Serta Hubunganya dengan Whistleblowing (Studi Persepsi Mahasiswa Akuntansi Universitas Islam Malang). Jurnal Akuntansi, 53(9), 63-77. https://doi.org/10.1017/CBO9781107415324.00 4 
Ikhsan, A. (2018). Metodologi Penelitian Bisnis. Medan: Madenatera.

LPSK. (2011). Memahami Whistleblower. Www.Lpsk.Com. www.lpsk.go.id

Malik, R. (2010). Analisis Perbedaan Komitmen Profesional dan Sosialisasi Antisipatif Mahasiswa PPA dan Non-PPA pada Hubungannya dengan Whistleblowing. Skripsi. Universitas Diponegoro.

Pangesti.S.N dan Sri Rahayu. SE. M.Ak.Ak. ,CA. (2017). Pengaruh Komitmen Profesional Dan Sosialisasi Antisipatif Mahasiswa Akuntansi Terhadap Whistleblowing (Studi Empiris Pada Mahasiswa Akuntansi Universitas Telkom Di Bandung Tahun Akademik 2015/2016. EProceeding of Accounting, 4(3), 2750-2761.

Prasasti, N. I. (2017). Komitmen Profesional, Sosialisasi Antisipatif dan Locus of Contro: pengaruhnya terhadap perialaku whistleblowing (Studi Kasus pada Staf Keuangan Dinas Pemerintahan Kabupaten Boyowali). In Skripsi. IAIN Surakarta.

Riyandhi. (2019). Tak Sesuai Target, Unimal Alihkan Beasiswa Bidikmisi. Www.Unimalnews.Com. http://news.unimal.ac.id/index/single/37/taksesuai-target-unimal-alihkan-beasiswabidikmisi.

Robbins, Stephen P. (2009). Prilaku Organisasi. Buku 1 Edisi 12.

Setiyawan, K. (2016). Analisis Perbedaan Komitmen Profesional dan Sosialisasi Antisipatif Mahasiswa UDINUS dan UNIKA Soegijapranata pada Hubunganya dengan Whistleblowing. Jurnal Akuntansi, 53(9), 16891699.

https://doi.org/10.1017/CBO9781107415324.00 4.

Sofiana. (2013). Kajian Empiris Tentang Niat Whistleblowing Pegawai Pajak. jurnal Akutansi. Vol. 01 No. 1.

Sugiyono. (2012). Metode Penelitian Kuantitatif, Kuallitatif, dan $R \& d$. Bandung: Alfabeta.

Surat Edaran Mahkamah Agung Nomor 4 Tahun 2011 tentang Perlakuan terhadap

Pelapor Tindak Pidana (whistlebower) dan Saksi Pelaku yang Bekerjasama.

Undang-Undang Republik Indonesia Nomor 13 Tahun 2011 tentang Perlindunngan Saksi dan Korban. 
